\title{
EXPRESSION OF MATRIX METALLOPROTEINASES 2 AND 9 AND TGF-B IN LIGAMENTUM FLAVUM HYPERTROPHY
}

\author{
EXPRESSÃO DAS METALOPROTEINASES 2 E 9 DA MATRIZ E DO TGF-B NA HIPERTROFIA \\ DO LIGAMENTO AMARELO
}

\author{
EXPRESIÓN DE METALOPROTEINASAS 2 Y 9 DE LA MATRIZ Y DEL TGF-B EN LA \\ HIPERTROFIA DEL LIGAMENTO AMARILLO
}

Marcelo Ferraz de Campos ${ }^{1}$, Cintia Pereira de Oliveira ${ }^{1}$, Maria Aparecida da Silva Pinhal ${ }^{1}$, Luciano Miller Reis Rodrigues ${ }^{1}$

\begin{abstract}
Objective: To evaluate the expression of matrix metalloproteinases and TGFb in patients with spinal stenosis and in younger patients who have herniated disc. Methods: 19 samples of LA were analyzed, nine of them with lumbar canal stenosis and 10 with disc herniation. Of the total, five patients were aged between 15 and 40 years, 10 were between 40 and 65 years and four had more than 65 years. Representative areas of LF were chosen based on the staining of tissues with hematoxylin-eosin. The $3 \mu \mathrm{m}$-thick sections embedded in paraffin and fixed in formalin were deparaffinized and rehydrated. All ligaments were incubated overnight at $4{ }^{\circ} \mathrm{C}$ with primary antibodies. Results: An increase of TGFb was verified in older individuals, although without statistical significance. Conclusion: Metalloproteinases showed no significant difference between both groups with respect to age and type of abnormality of the spine.
\end{abstract}

Keywords: Ligamentum flavum; Metalloproteinases; Spinal stenosis.

\section{RESUMO}

Objetivo: Avaliar a expressão das metaloproteinases e do TGFb em pacientes com estenose do canal vertebral e em pacientes mais jovens que apresentam hérnia de disco. Métodos: Foram analisadas 19 amostras de LA, sendo nove de pacientes com estenose de canal lombar e 10 de pacientes com hérnia discal. Do total, cinco pacientes tinham de 15 a 40 anos, 10 tinham de 40 a 65 anos e quatro tinham mais de 65 anos. As áreas representativas do LA foram escolhidas com base na coloração dos tecidos por hematoxilina-eosina. Os cortes de $3 \mu \mathrm{m}$ de espessura incluídos em parafina e fixados em formalina foram desparafinizados e reidratados. Todos os ligamentos foram incubados overnight a $4^{\circ} \mathrm{C}$ com os anticorpos primários. Resultados: Constatou-se aumento do TGFb em indivíduos mais velhos, embora sem significância estatística. Conclusão: As metaloproteinases não apresentaram diferença importante entre os grupos tanto com relação à idade quanto ao tipo de alteração da coluna vertebral.

Descritores: Ligamento amarelo; Metaloproteinases; Estenose espinal.

\section{RESUMEN}

Objetivo: Evaluar la expresión de metaloproteinasas de la matriz y del TGFb en pacientes con estenosis espinal y en pacientes más jóvenes que tienen una hernia de disco. Métodos: Diecinueve muestras de LA fueron enviadas, de nueve pacientes con estenosis del canal lumbar y diez pacientes con hernia de disco. Del total de pacientes, cinco tenían de 15 a 40 años, 10 tenían de 40 a 65 años y cuatro tenían más de 65 años. Áreas representativas de LA se eligieron sobre la base de la tinción de los tejidos con hematoxilina-eosina. Las secciones de $3 \mu$ m de espesor, incluidas en parafina y fijadas en formalina fueron desparafinadas y rehidratadas. Todos los ligamentos se incubaron durante la noche a $4{ }^{\circ} \mathrm{C}$ con anticuerpos primarios. Resultados: Se encontró un aumento de TGFb en personas mayores, aunque sin significación estadística. Conclusión: Las metaloproteinasas no mostraron diferencias significativas entre ambos grupos con respecto a la edad y el tipo de anomalía de la columna vertebral.

Descriptores: Ligamento amarillo; Metaloproteinasas, Estenosis espinal.

\section{INTRODUCTION}

With the aging of the population, the incidence of diseases of the spine has increased, narrowing of the spinal canal being one of the main causes of pain and functional limitation in elderly patients. The cause of this narrowing may be due to facet arthrosis, disc bulging and in particular, ligamentum flavum hypertrophy (LFH). ${ }^{1}$ The factors related to hypertrophy of this ligament have been partially elucidated, and no effective prophylaxis or treatment option, except for decompression surgery, has been well established.

Histologically, the ligamentum flavum is composed of $70 \%$ elastic fibers and $30 \%$ collagen fibers, which are arranged parallel to each other in layers. ${ }^{2,3}$ During hypertrophy of the ligamentum flavum, there is reduction in the content of elastic fibers and an increase in collagen fibers, calcification, ossification and chondrometaplasia. ${ }^{4-6}$
Sairyo et $a^{7,8}$ have shown a correlation between the hardening of the ligamentum flavum and the degree of fibrosis, resulting in repetitive inflammatory processes due to the mechanical stresses that the ligament suffers during the movements of the spine. Park and collaborators demonstrated that an increase in TGFb (transforming growth factor beta) expression, the protein that controls cell proliferation and acts in the early stages of oncogenesis, is related to hypertrophy of the ligamentum flavum. ${ }^{9}$

In the attempt to develop future therapeutic options, it will be necessary to understand whether the hypertrophy originates in the biomechanical stress caused by movement of the spine, or whether this process is due to inflammatory changes in the disc and adjacent tissues that increase the risk of inflammation of the ligamentum flavum, and its hypertrophy. According to this theory, patients with

1. Faculdade de Medicina do ABC (FMABC), Santo André, SP, Brazil. 
a history of intervertebral disc disease would have a higher predisposition to develop changes in the ligamentum flavum in the future.

The objective of our study is to evaluate the expression of matrix metalloproteinases and TGFb in the ligamentum flavum in patients with stenosis of the spinal canal, and in younger patients with other diseases of the spine, such as herniated disc.

\section{METHOD}

We studied 19 samples of ligamentum flavum (deep region) of individuals with stenosis of the lumbar canal and disc herniation, collected by the surgeon in the period May 2013 to January 2014 , using nuclear magnetic resonance images of the segment of the lumbar spine to complement the diagnosis. These ligaments were obtained during surgery for the treatment of a herniated disc and lumbar canal stenosis. The study was approved by the Research Ethics Committee of the Faculdade de Medicina do ABC.

The subjects were divided into three groups according to age: under 40 years, between 40 and 65 years, and over 65 years. In relation to age: group I, 15 to 40 years, had five samples (average age: 29.2), group II, 40 to 65 years, had ten samples (average age: 48.4) and group III, over 65 years, had four samples (average age: 74). In relation to pathology: group I, lumbar canal stenosis, had nine patients and group II, disc herniation, had ten patients.

The inclusion criteria were:

In the disc herniation group: extruded fragments located in the central-lateral region of the vertebral canal, more than three months of symptoms, without previous surgery of the lumbar segment and location of the disc herniation in segment L4-L5 or L5-S1.

In the stenosis of the lumbar canal group: main complaint of neurogenic claudication, main factor of compression of the lumbar canal to hypertrophy of the ligamentum flavum, location of the stenosis in segment L4-L5 or L5-S1.

\section{Immunohistochemistry}

Representative areas of the ligamentum flavum were selected based on the staining of tissue sections with hematoxylin-eosin $(\mathrm{HE})$. Sections $3 \mu \mathrm{m}$ thick, embedded in paraffin and fixed in formalin, were deparaffinized and rehydrated.

Recovery of the antigen was performed by heating the slides to $100{ }^{\circ} \mathrm{C}$ for 30 minutes in a citrate buffer $10 \mathrm{mmol} / \mathrm{L}, \mathrm{pH} 6.0$. The endogenous peroxidase activity was blocked with an aqueous solution of $3 \%$ hydrogen peroxide, for 35 minutes.

The sections were then incubated overnight at $4^{\circ} \mathrm{C}$ with the primary antibodies: anti-decorin ( $\mathrm{N}-15)$, anti-biglycan (L-15), TGF $\beta 1$ (sc-146), anti-MMP-9 $(\mathrm{H}-129)$, and anti-MMP-2 $(\mathrm{H}-76)$ (Santa Cruz Biotechnology, CA, USA). Finally, the slides were incubated with a complex of peroxidase-labeled streptavidin (LSAB ${ }^{\circledR}$, DakoCytomation, Glostrup, Denmark) for 30 minutes. The sections were revealed using 3,3'-diaminobenzidine (DAB) for 1 minute and were contrastained with hematoxylin. Some samples were incubated with phosphate buffer $1 \mathrm{M}$ in the absence of primary antibody, as negative controls. The presence of brown staining was considered as evidence of positive expression of the respective molecules in the cell.

\section{Digital quantification}

The slides were analyzed under a TS100 Nikon Eclipse ${ }^{\circledR}$ light microscope to identify areas that best represented the immunostaining of the molecules analyzed (hot spots). In each case, the quantification of immunostaining was performed by a method of digital analysis by computer. The $640 \times 480$ pixel photomicrographs were obtained from non-coincident consecutive fields at $400 \mathrm{X}$ magnification with a 4300 Nikon Coolpix ${ }^{\circledR}$ digital camera adjusted for the same parameters. The images were analyzed by the system for image processing and analysis ImageLab ${ }^{\circledR}$ (Softium Informática ${ }^{\circledR}$, São Paulo, Brazil), adjusted to the micrometric scale $(\mu \mathrm{m})$.

\section{Index of positivity (IP)}

In each case, at least 1,000 cells were counted by ImageLab ${ }^{\circledR}$, and the observer classified as cells that are positive or negative. For this reason, the percentage of labeled cells was determined according to the following equation:

$$
\mathrm{IP}=\underline{\text { number of labeled cells }} \times 100(\%)
$$

total cells counted

\section{Intensity of expression (IE)}

The ImageLab ${ }^{\circledR}$ was used to quantify the intensity of the brown color that resulted from the immunostaining. For each case, the same photomicrographs that were used to determine the IP were considered. Twelve cytoplasmic regions of different cells, randomly labeled, were accessed with the same-sized square (tool from the ImageLab ${ }^{\circledR}$ system). The mean optical density (OD) of these areas was automatically calculated and represents the average compositions of colors red, green and blue (RGB) per area of cytoplasm analyzed; the OD was expressed in optical units by square micrometer $\left(\mathrm{ou} / \mu \mathrm{m}^{2}\right)$. The same procedure was applied to obtain the background optical density (BOD) of an area without tissue or vascular space for each photomicrography. A single area was sufficient for this purpose, because the background is homogeneous in each image. The absolute white color, which corresponds to the maximum optical density $\left(320.7 \mathrm{ou} / \mu \mathrm{m}^{2}\right)$ is composed of a complete mixture of red, green, and blue, while black represents the absence of these colors. Therefore, the optical density values calculated by the program comprised a decreasing scale, with the highest values corresponding to the colors that were clearly visible. The equation shown below was used to calculate the digital intensity of expression (IE) in each case. Their values comprised an increasing scale that is subtracted from the BOD proportional to the optical density of the absolute white.

$$
\mathrm{IE}=320.7-\frac{320.7 \times \sum \mathrm{OD}}{\sum \mathrm{BOD}} \quad\left[\mathrm{ou} / \mu \mathrm{m}^{2}\right]
$$

\section{Expression index (EI)}

The digital expression index (DEI) was obtained by multiplying the percentage of labeled cells (PLC) by the digital immunolabeling index (DII) for each case, using the following equation:

$$
\mathrm{EI}=\frac{\mathrm{IP} \times \mathrm{IE}}{100} \quad\left[\mathrm{ou} / \mu \mathrm{m}^{2}\right]
$$

\section{RESULTS}

In relation to age, there was an increase in TGFb expression in patients aged over 65 years. Of metalloproteinases 2 and 9, only 9 showed an increase by age, but without statistically significant variation. (Figures 1-3)

The stenosis of the lumbar canal group presented higher TGFb expression compared with the disc herniation group. (Figures 4-6) Metalloproteinases 2 and 9 showed greater expression in the disc herniation group compared with the lumbar canal stenosis group, but without statistically significant variation.

\section{DISCUSSION}

In neurogenic claudication, due to the osteoligamentary stenosis, there is a degenerative process that occurs in elderly patients. These changes cause pain, significant functional limitation, and neurological changes. The precise reason for the hypertrophy of the ligamentum flavum is little known, but the mechanism of mechanical stress is believed to be the main etiological factor; the precise reason for this progressive hypertrophy is still unknown. Neither do we know whether there is some factor that triggers these changes in the ligamentum flavum, besides mechanical stress; for example, inflammation of the surrounding tissues, such as the intervertebral disc. 


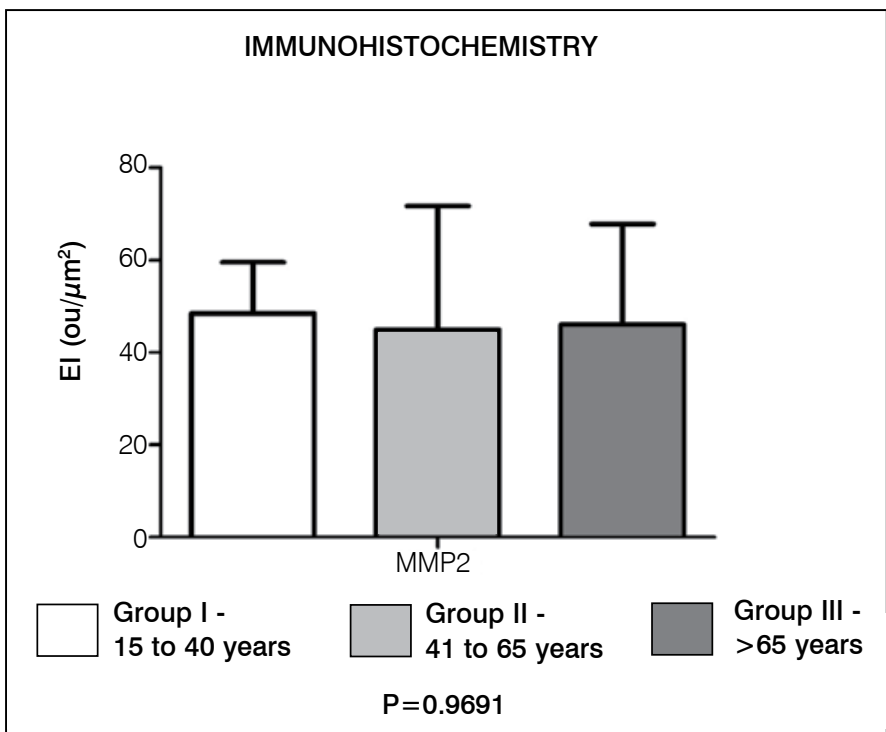

Figure 1. Evaluation of metalloproteinase 2 expression in the different age groups.

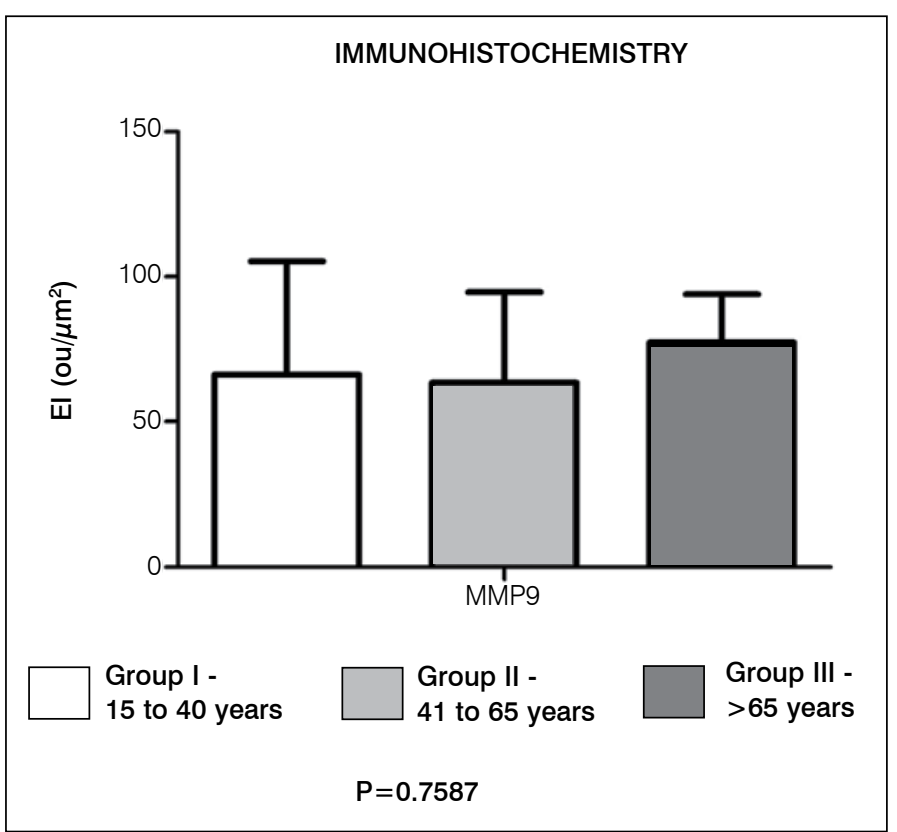

Figure 2. Evaluation of metalloproteinase 9 expression in the different age groups.

Lohr et a/ ${ }^{10}$ demonstrated a significant presence of inflammatory infiltrate in the peripheral region of the hypertrophied ligamentum flavum composed mainly of macrophages, endothelial cells and T lymphocytes, corresponding to a chronic immune reaction. These cells presented significant TGFb expression, known as an important factor of arrangement of extracellular collagen. This inflammation may, therefore, be an important factor in the progression of hypertrophy of the ligamentum flavum, due to the replacement of elastic fibers by collagen fibers. Our study showed an increase in TGFb expression in patients with stenosis of the lumbar canal with hypertrophy of the ligamentum flavum, but there was also an increase in TGFb expression in individuals with lumbocytalgia due to lumbar disc herniation. Our hypothesis is that significant changes in the intervertebral disc can influence changes in the ligamentum flavum, but to clarify this, we would need to study different intervertebral disc changes and their relationship to the ligamentum flavum.

The research was carried out with a low number of samples, and does not show significant differences in the evaluation of the

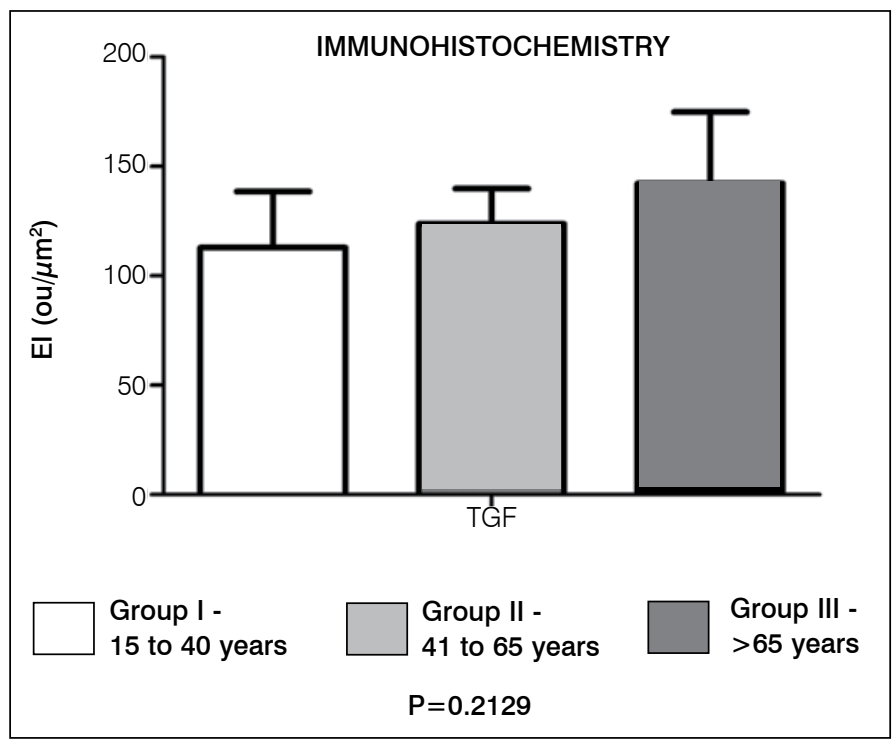

Figure 3. Evaluation of TGFb expression in the different age groups.

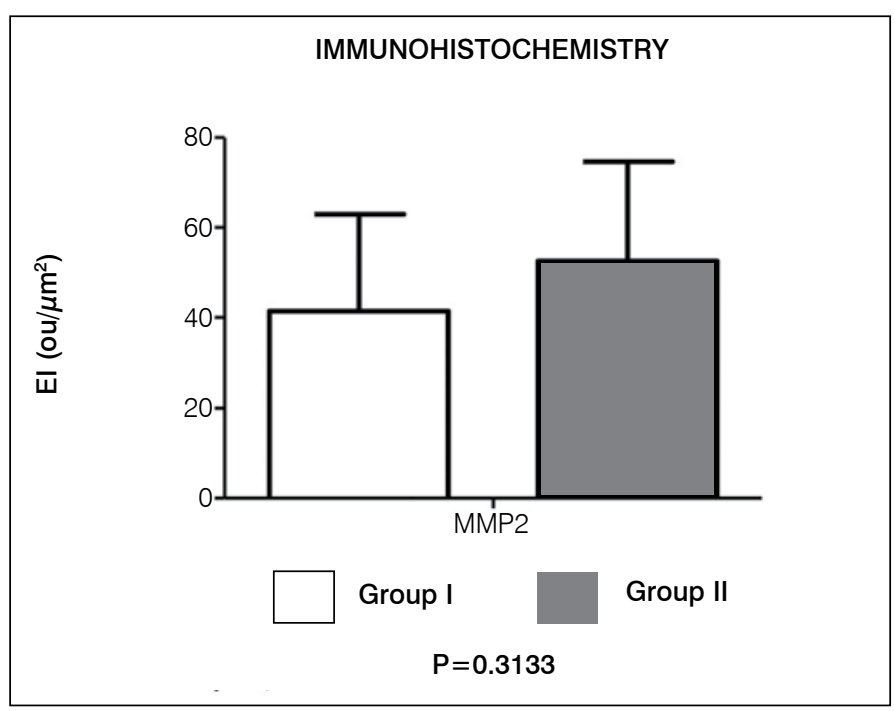

Figure 4. Evaluation of metalloproteinase 2 expression in relation to the disease: group I - canal stenosis; group II - disc herniation.

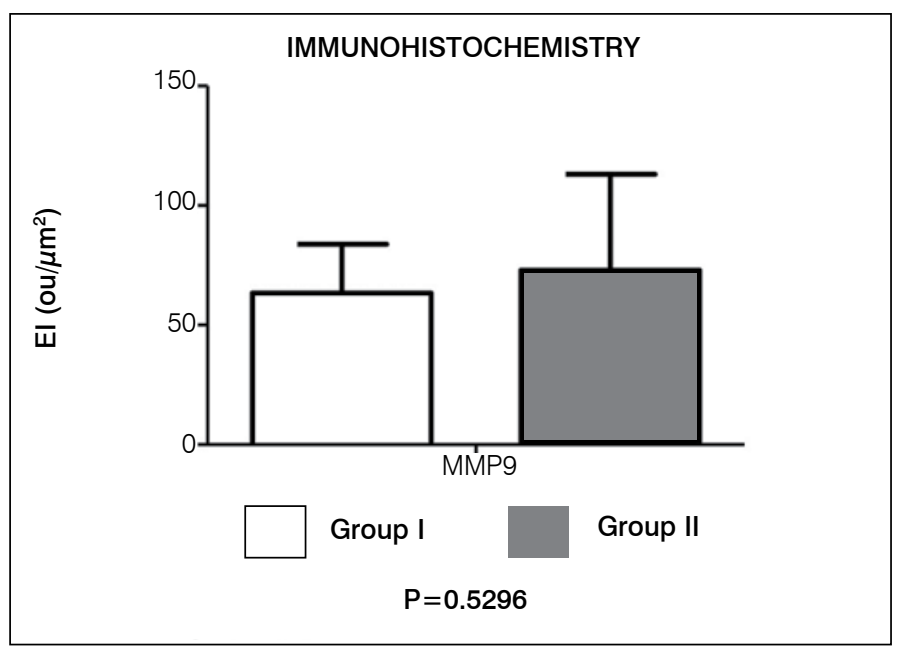

Figure 5. Evaluation of metalloproteinase 9 expression in relation to the disease: group I - canal stenosis; group II - disc herniation. 


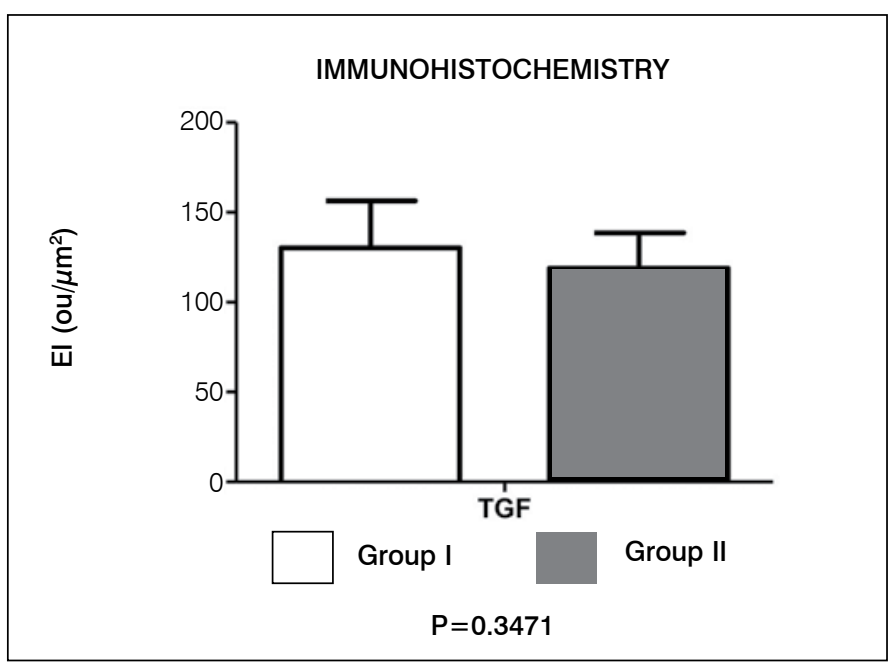

Figure 6. Evaluation of TGFb expression in relation to the disease: group I - canal stenosis; group II - disc herniation.

material analyzed. The results may contribute to more advanced studies that elucidate the molecular mechanisms for the development of target molecules for new therapies, or other forms of diagnosis/prognosis of the process of degeneration of the ligamentum flavum.

The metalloproteinases are responsible by the degradation and modification of the extracellular matrix, and include more than 20 types. Metalloproteinases 2 and 3 are closely associated with degradation of the matrix of the joint cartilage and intervertebral disc. ${ }^{11}$ Soo and Kee-Young ${ }^{12}$ showed, in their study, that in degenerative spondylolisthesis, the mechanical stress to which the ligamentum flavum is submitted leads to an increase in metalloproteinase expression. This biomechanical stress occurs due to vertebral laxity and tensional instability of the ligament structures of the spine. ${ }^{12}$ In our study, there was an increase in expression of the metalloproteinases in both groups, with patients with disc herniation presenting a greater increase, compared with the stenosis of the lumbar canal group, adding the inflammatory factor to the biomechanical hypothesis of Soo and Kee-Young. ${ }^{12}$

Saiyro et $a l^{8}$ detected the presence of inflammatory cytokines, such as COX-2 and interleukin 1, 6, 8 and 15 in ligaments with and without increased thickness. They also demonstrated, in their article, that RNAm expression of these inflammatory cytokines occurs before the actual ligament hypertrophy. We show, in our study, that in patients without hypertrophy of the ligamentum flavum, there was also an increase in metalloproteinases and TGFb expression.

\section{CONCLUSION}

There was an increase in TGFb in older individuals, although without statistical significance. The metalloproteinases did not present any significant differences between the groups, either in relation to age, or to the type of alteration in the spine.

All authors declare no potential conflict of interest concerning this article.

\section{REFERENCES}

1. Szpalski M, Gunzburg R. Lumbar spinal stenosis in the elderly: an overview. Eur Spine J. 2003;12(Suppl 2):S170-5

2. Nachemson AL, Evans JH. Some mechanical properties of the third human lumbar interlaminar ligament (ligamentum flavum). J Biomech. 1968;1(3):211-20.

3. Yahia LH, Garzon S, Strykowski H, Rivard CH. Ultrastructure of the human interspinous ligament and ligamentum flavum. A preliminary study. Spine (Phila PA 1976). 1990;15(4):262-8.

4. Fukuyama S, Nakamura T, Ikeda T, Takagi K. The effect of mechanical stress on hypertrophy of the lumbar ligamentum flavum. J Spinal Disord. 1995:8(2):126-30.

5. Ramani PS, Perry RH, Tomlinson BE. Role of ligamentum flavum in the symptomatology of prolapsed lumbar intervertebral discs. J Neurol Neurosurg Psychiatry. 1975;38(6):550-7.

6. Postacchini F, Gumina S, Cinotti G, Perugia D, DeMartino C. Ligamenta flava in lumbar disc herniation and spinal stenosis. Light and electron microscopic morphology. Spine (Phila Pa 1976). 1994;19(8):917-22.

7. Sairyo K, Biyani A, Goel V, Leaman D, Booth R Jr, Thomas J, et al. Pathomechanism of ligamentum flavum hypertrophy: a multidisciplinary investigation based on clinical, biomechanical, histologic, and biologic assessments. Spine (Phila Pa 1976). 2005:30(23):2649-56.

8. Sairyo K, Biyani A, Goel VK, Leaman DW, Booth R Jr, Thomas J, et al. Lumbar ligamentum flavum hypertrophy is due to accumulation of inflammation-related scar tissue. Spine (Phila Pa 1976). 2007;32(11):E340-7.

9. Park JB, Lee JK, Park SJ, Riew KD. Hypertrophy of ligamentum flavum in lumbar spinal stenosis associated with increased proteinase inhibitor concentration. J Bone Joint Surg Am. 2005;87(12):2750-7.

10. Löhr M, Hampl JA, Lee JY, Ernestus RI, Deckert M, StenzelW. Hypertrophy of the lumbar ligamentum flavum is associated with inflammation-related TGF- $\beta$ expression. Acta Neurochir (Wien). 2011;153(1):134-41.

11. Visse $\mathrm{R}$, Nagase $\mathrm{H}$. Matrix metalloproteinases and tissue inhibitors of metalloproteinases: structure, function, and biochemistry. Circ Res. 2003;92(8):827-39.

12. Oh IS, Ha KY. Matrix metalloproteinase-3 on ligamentum flavum in degenerativelumbar spondylolisthesis. Spine (Phila Pa 1976). 2009;34(16):E552-7. 